\author{
LIUBOV ZHAROVA, \\ University of Economics and Humanities (Bielsko-Biała, Poland) \\ e-mail: zharova.l@gmail.com, ORCID 0000-0002-3568-775X
}

ANNA CHECHEL,

Donetsk State University of Management (Mariupol, Ukraine)

e-mail: annachechel.ac@gmail.com, ORCID 0000-0003-4307-5574

\title{
HISTORICAL ASPECTS OF SUSTAINABLE DEVELOPMENT AND ECONOMIC EVOLUTION INTERCONNECTION
}

The research is based on idea that sustainable development like a basic idea remains the same from the beginning but its content, priorities, and methods are evolving simultaneously with the economy. The comprehensive analysis of stages of evolution and prognosis of economic development will give a clue of the future sustainable priorities. Evolutionary changes in the economy created the background and incentives to the concept of sustainable development progress. The main idea of sustainable development, which could be briefly described like balancing between the scarcity of resources and infinity of ideas (desires) for an uncertain long period of time, is consistent with the basic principles of the economy. That gives us a possibility to predict when the next step in sustainable development will be done in accordance with the world economic dynamic. Systematization and analysis of economic development through the prism of sustainable development give us a clue for understanding instigators in the sustainable development evolution: The necessity of overcoming economic resections and crises in the most efficient and effective way. That means that we also need new ideas, new imperatives for development and basis for overcoming social inequity which has been deepening during every economic trouble and slowed down the reforming because of low governmental support; the increasing world inequality which exacerbates the global imbalance and at the end slows down the world economic development. The evolution becomes possible when coming through all stages of evolutionary development de-coordination, re-coordination, new order. The first phase corresponds to the creation of a point of disturbance, which could be a potential source of growth or change. The second phase is the process of re-coordination of macrolevel (macro order) as a result of continuing dissatisfaction of local unites and the impossibility of meso level to solve them. The third phase is the creation of the new order, different from the older one by its approaches, methods, tools for solving the problems raised from the microlevel and also added through globalization processes and openness. This is the evolution of sustainable development, and these processes can be tracked and predicted through the evolutionary economy.

Key words: evolutionary economy; sustainable development; economic history; economics; development; economic theory; globalization.

\section{Introduction}

Sustainable development (SD) has become a popular catchphrase in contemporary development discourse. However, in spite of its pervasiveness and the massive popularity it has garnered over the years, the concept still developing and transforming. The classical definition of sustainable development - this is the development that meets the needs of the present without compromising the ability of future generations to meet their own needs (Our Common Future, 1987).

The idea of "sustainable development" as a system of views of the ideologists in the Club of Rome, having emerged in the 1960-70s, generated agitated scientific and sociopolitical debates, involving the problems of the economy version, under which, based on the rational use of all resources, the use of new technologies and organizational management tools will secure the environment and the conditions for the development of the society in the future (Akhmedova, 2019).

ISSN 1728-9343 (Print)

ISSN 2411-3093 (Online)
We should underline that it is actually closely correlated with traditional economics ideas about the keystones of the economy - Scarcity, Choice, and Cost. Something is scarce if the choice of one alternative requires that another will be given up. The existence of alternative uses also forces us to make choices. The opportunity's cost of any choice is the value of the best alternative forgone in making it that is why the latest research is moving to social from the mathematical spheres of economy. One more pillar of the economics is the idea that our resources are limited. That means that at any one time, we have only the defined set of resources of any kind (from natural to the virtual one), but our wants, our desires for the things that we can produce with those resources, are unlimited. We will always strive for more and better. Virtually everything is scarce.

This scarcity makes the idea of sustainability actual and crucial for a long period, and the vitality of it based also on the world population forecast (fig. 1) which will also endeavor more.

SKHID No. 2 (166) March-April 2020 


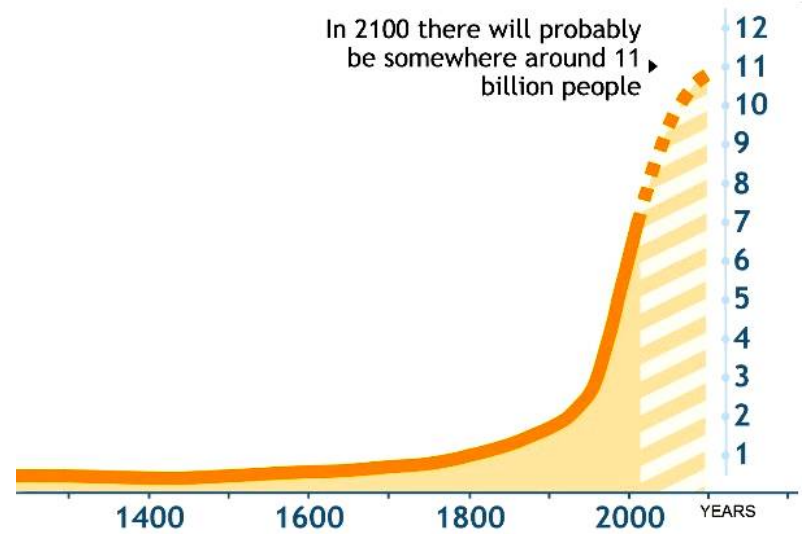

Fig. 1. UN World Population Forecast, billion people. Source: (Rosling, 2012)

Idea, methods and results of the research

The hypotheses of the presented research are that sustainable development like a basic idea remains the same from the beginning but its content, priorities, and methods evolving simultaneously with the economy. The comprehensive analysis of stages of evolution and prognosis of economic development will give a clue of future sustainable priorities.

The first step in research - we should outline the "definitions" field on which further research will be built on. Evolutionary economics as a theory was first coined by Thorstein Veblen (1857-1929), an American economist and sociologist (Sowell, 1967). The theory states that evolutionary economics proposes that economic processes evolve and are determined by both factors: individuals and society as a whole; it shuns the rational choice theory of traditional economics, arguing that psychological factors are the key drivers of economy; economists in this field seek to explain economic behavior and progress in relation to evolution and evolutionary human instincts.

There is a need to distinguish between economic growth and economic evolution. According to the International Monetary Fund - economic growth is required for sustainable social development ${ }^{1}$. Fig. 2 demonstrates one of the environmental consequences of economic growth -

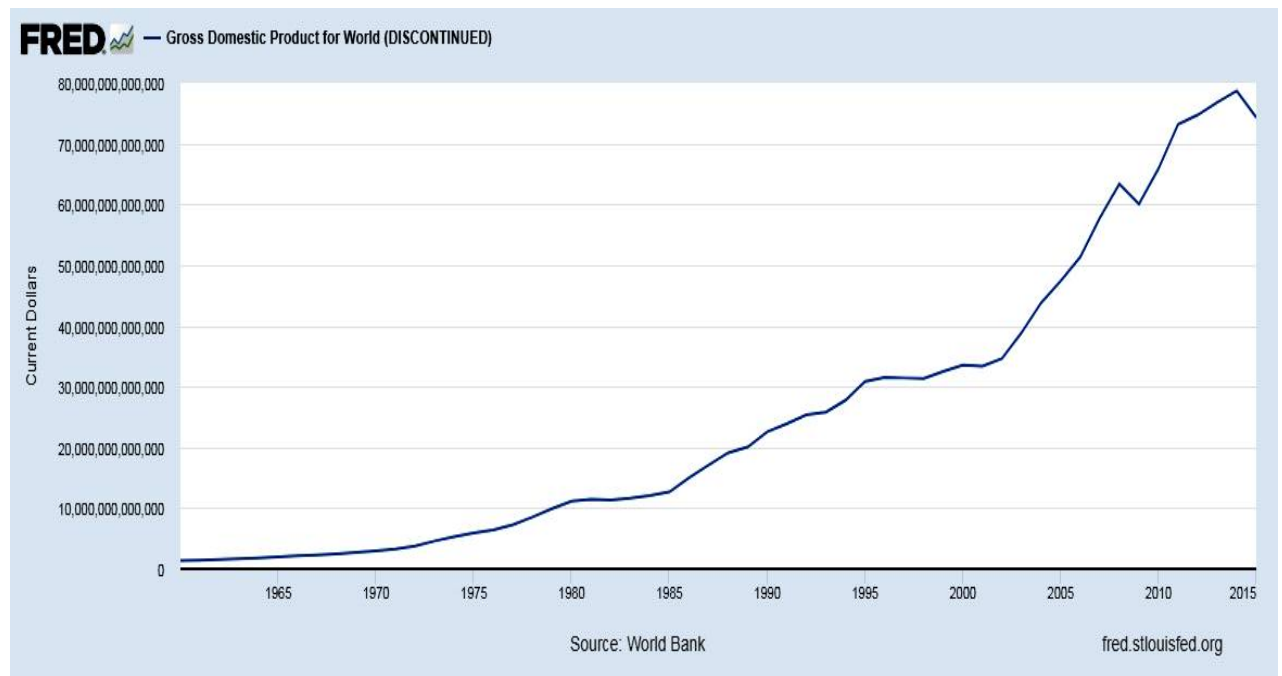

GDP in current dollars

Annual total $\mathrm{CO}_{2}$ emissions, by world region
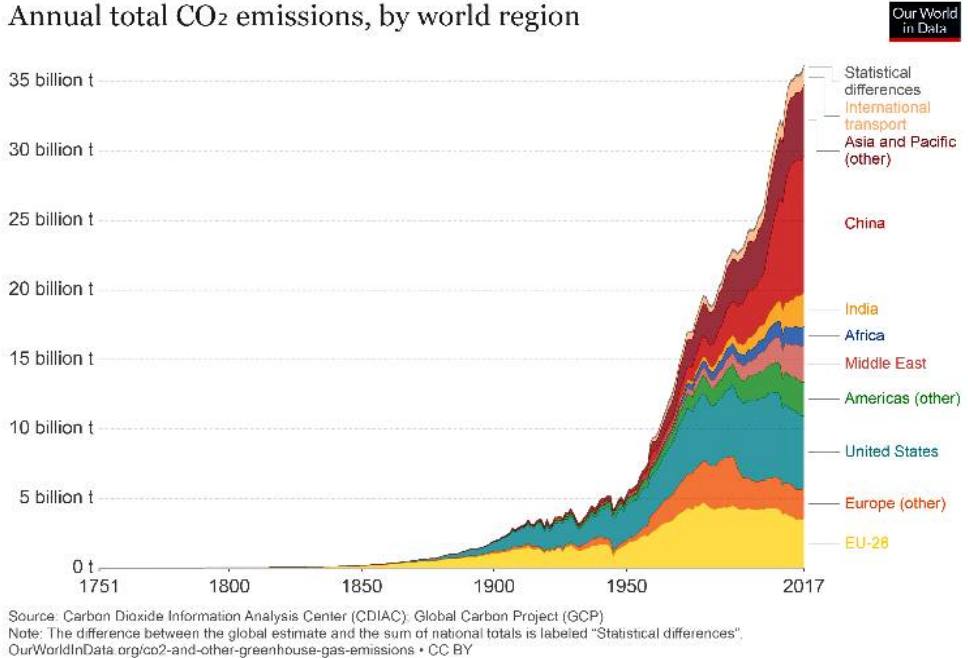

CO2 emissions, $b$ tons

Fig. 2. The GDP and CO2 emission growth. Source: FRED and World Open Data

\footnotetext{
${ }^{1}$ Sustained Economic and Social Development: The IMF's Perspective". Online recourse. Retrieved from https://www.imf.org/external/ pubs/ft/pam/pam47/pam4702.htm
} 
the increasing level of $\mathrm{CO} 2$ emissions in dynamic from the year 1750 till today. The accelerating economic development leads to raising the pressure on the environment that affected all aspects of life (directly or indirectly). In the last few years, a broader concept of high-quality growth has emerged, namely, economic growth that brings lasting employment gains and the poverty reduction, provides greater equality of income through greater equality of opportunity, including women, and respects human freedom and protects the environment.

But economic growth is not the same as economic evolution. Understanding the differences and stages is developing also.

L. White (1959) defined evolutionism as a temporal sequence of form in its most irreducible forms, for no stage of civilization came into existence spontaneously, but grew or was developed out of the stage before it. Thus, he proposed the "ladder" form or non-linear form of evolution of societies.

T. Hobbes (1651) claimed that before the appearance of modern governments and states, life was "solitary, poor, nasty, brutish and short" (Hobbes, 2010).

During the eighteenth and nineteenth centuries, many famous authors - economists (Smith per Meek, Raphael, \& Stein; Turgot etc.) as well as anthropologists (Morgan) adopted linear vision to describe the evolution of human societies. They described the economic development of human societies as a sequence of four stages: the age of hunting and gathering, that of pastoralism, that of agriculture and finally that of commerce, the latter involving among other things foreign trade and manufacturing (Svizzero, Tisdell, 2016).

Adam Smith's views on the stages and nature of development of human societies were distilled primarily from a copy of his lecture notes to students on the subject of jurisprudence (Brewer, 2008).

Along with this expansion of economic value (measured as growth) economic history also reveals significant structural changes in the content of the 'knowledge-base' of an economy (Silverberg and Verspagen, 2005). Economic evolution is a process that occurs at the generic level of the economic order, an analytic level that refers to the ideas, rules and knowledge, which constitute the basis of economic operations. The operational level of the economy may fluctuate, grow and shrink, but change at the generic level of the economy is always an evolutionary process (Dopfer, Potts, 2007). Besides that, there is ongoing institutional change in the rules that compose the economic order. This structural and institutional change is an open process, in that new ideas, knowledge, patterns, connections and institutions can enter into the economic system,

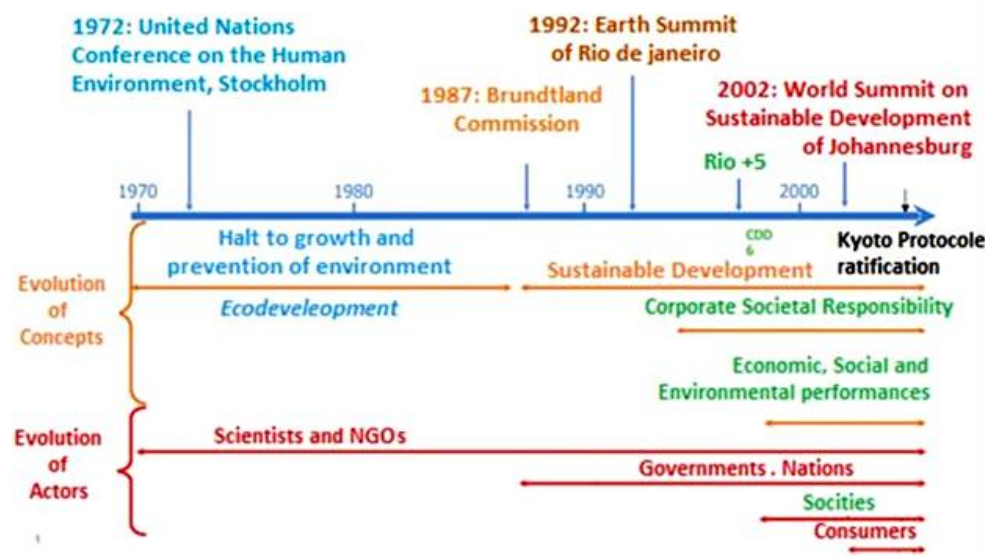

Fig. 3. Evolution of sustainable development. Source: (Cisneros-Saguilána at all, 2015; Zoheir, Abbar, 2017)

displacing extant rules, knowledge, etc. In other words, the pathway of an economic system is open and complex from the historical perspective (Landes, 1998; Nell, 1998; Mokyr, 2002). The Witt $U$. argued that novelty is a universal driver for evolution, its emergence and diffusion are abstract concepts - in fact, in wider sense, Schumpeterian principles - by which the unfolding processes can be logically structured (Witt, 2016). Evolutionary economics, then, is the study of the self-organizational process of coordination and of re-coordination of generic rules in consequence of change in generic rules actualized along the historical course of an evolutionary process.

Societies and their economic systems have changed greatly since prehistoric times. The recent stages of economic development have resulted in increasing globalization and as a result of social institution has become increasingly important (and local environmental factors less so) in determining the evolution of human societies (Svizzero, Tisdell, 2016). This has resulted in reduced global socioeconomic diversity as Western-type marketbased systems have increasingly dominated all others. A worrying result is that the embedding of individuals within this system (increased ultra-sociality) could result in them having little control over their future development (so-called VUCA world) and increasing the pressure on the environment constantly.

The second step - we analyze evolution of sustainable development itself. Technological and industrial development and growth of population that accompanied increasing of prosperity and longevity naturally led do rising of consuming and jeopardizing the natural resources' availability. Scientists and philosophers thought about other understanding of human development based on harmony with the world (like a noosphere (Levit, 2000)) more than pure economic development; they frightened with limits of growth (Meadows, Meadows, Randers, Behrens, 1972) and tragedy of commons (Hardin, 1968) and warn about the consequences of uncontrolled growth.

Their endeavors to change common understanding of the true price of economic development firstly touch the nongovernmental organizations then all together stimulated rising the awareness of international organizations and governmental institutions and united them for mutual discussion and reviewing policies and politics, afterword it affected ordinary citizens and only then it caused change the entrepreneurs' view of the situation. Nowadays the results of this evolution of processes of finding the balance in economic, social and environmental development are generalized in the concept of sustainable development (fig. 3).

1992: Earth Summit

of Rio de janeiro

Environment, Stockholm

of Johannesburs le 
The sustainable development progress is a movement from board declaration for all to reginal and local strategies, and way from generalized indicators and tools for designing the specific adoptative set of tools and localized indicators and goals for every country (region, community).

1972 - The United Nations Conference on the Human Environment (also known as the Stockholm Conference) was an international conference convened under the United Nations auspices held in Stockholm, Sweden. It was the UN's first major conference on international environmental issues, and marked a turning point in the development of international environmental politics.

1983 - The General Assembly - the establishment of a special commission that should make available a report on environment and the global problematic to the year 2000 and beyond, including proposed strategies for sustainable development. The commission later adopted the name World Commission on Environment and Development.

1992 - Earth Summit - high profile meetings had achieved a global consensus on the priorities for a new development agenda for the 1990s and beyond. The subsequent chapters of this briefing paper, each dedicated to one of the major conferences, attempted to answer important questions about problems, actions, tools and instruments.

2000 - UN Millennium Declaration - the UN General Assembly adopted some 60 goals regarding peace; development; environment; human rights; the vulnerable, hungry, and poor; Africa; and the United Nations.

2001 - The European Union Strategy for Sustainable Development - regional document for bridging the gap between this ambitious vision and practical political action, the Commission proposed that the strategy should focus on a small number of problems which posed severe or irreversible threats to the future well-being of European society

2002 - Johannesburg Summit -brought together tens of thousands of participants, including heads of State and Government, national delegates and leaders from nongovernmental organizations (NGOs), businesses and other major groups to focus the world's attention and direct action toward meeting difficult challenges, including improving people's lives and conserving our natural resources in a world that was growing in population, with everincreasing demands for food, water, shelter, sanitation, energy, health services and economic security.

2006 - The Renewed EU Sustainable Development Strategy - the overall aim of the renewed EU SD was to identify and develop actions to enable the EU to achieve continuous improvement of quality of life both for the current and future generations, through the creation of sustainable communities who were able to manage and use resources efficiently and tap the ecological and social innovation potential of the economy, ensuring prosperity, environmental protection and social cohesion.

2007 - Beyond GDP conference - the next step for understanding, implementing and estimating SD. Beyond GDP initiative was about developing indicators that were as clear and appealing as GDP, but more inclusive of environmental and social aspects of progress.

2009 - Stiglitz reported an attempt from the Nobel Nominee to rethink the traditional economic development in the framework of sustainable development.

2010 - The Europe 2020 strategy provided a framework for the coordination of economic policies across the European Union in the context of SD.

2012 - Rio +20 Meeting - renewed plans and aims for SD cooperation.
2013 - The establishment of the United Nations Highlevel Political Forum on Sustainable Development (HLPF) - the Forum met annually under the auspices of the Economic and Social Council for eight days, including a three-day ministerial segment and every four years at the level of Heads of State and Government under the auspices of the General Assembly for two days.

2014 - The UN report: The Road to Dignity by 2030: Ending Poverty, Transforming All Lives and Protecting the Planet - A new attempt to revise and specify the goals and ways of solving problems on the way towards the SD.

2015 - The Agenda 2030 - the latest document which defined SD goals and designed the modern platform for sustainable development implementation.

The historical analysis of SD development illustrates the general dynamic of research from the marco level to meso and then to microlevel.

Currently, most of the definitions and interpretations of sustainable development do not come from the comprehensive concepts of such development. Instead, they are influenced by the basic principles of specific groups or organizations of sustainable development (Mebratu, 1998; Zhao, Liang, Zhang, 1999; Kates, Parris, Leiserowitz, 2005). Based on the study (Mensah, Ricart Casadevall, 2019) of the evolution of sustainable thoughts and the formation of sustainable theory could be divided into the evolution and development of SD theory into the embryonic period (before 1972), the molding period (1972-1987), and the developing period (since 1987). Nowadays, sustainable development has been defined as development that meets the needs of the present without compromising the ability of future generations to meet their own needs. The main issues are:

- sustainable development calls for concerted efforts towards building an inclusive, sustainable and resilient future for people and planet.

- sustainable development to be achieved, it is crucial to harmonize three core elements: economic growth, social inclusion and environmental protection. These elements are interconnected and all are crucial for the well-being of individuals and societies.

- eradicating poverty in all its forms and dimensions is an indispensable requirement for sustainable development. To this end, there must be promotion of sustainable, inclusive and equitable economic growth, creating greater opportunities for all, reducing inequalities, raising basic standards of living, fostering equitable social development and inclusion, and promoting integrated and sustainable management of natural resources and ecosystems ${ }^{2}$.

As we stated earlier (Zharova, 2017) sustainable development is no longer just a field for scientific research; it is a framework for newest policy. Also, it is important to stress, that sustainable development is not limited by ecological problems, resource devastation and greening the economy. It is wider and more complex. Initially it is the idea of finding the balance between environmental, economic and social issue s for supporting the long-term prosperous development. Currently these tendencies could not be ignored anymore and success in modern conditions depends from understanding of new trends and requirements. Naturally, it changes the management, but these changes are not coercive, they are more result of evolving of the society

Summarizing this part of research, we could say that each step between milestones of sustainable development (1972: UN Conference on the Human Environment,

2 The Sustainable Development Agenda (2020). Retrieved from https://www.un.org/sustainabledevelopment/development-agenda/ 
Stockholm - 1987: Brundtland Report - 1992: UN Conference on Environment and Development, Rio de Janeiro 1997: Rio+5 Conference, New York - 2002: UN World Summit on Sustainable Development, Johannesburg 2012: Conference on Sustainable Development "Rio+20" - 2015 Agenda $2030 \ldots$..) were made not only because political dash of countries (one asking for help and equality, others for dividing the presser of help equally) or because of awareness of the size and inevitability of the problems became clear for all, but as a result of evolutionary changes in the economic development.

The third step - interconnection between sustainable development and economic evolution. For the basis we take the research of J. Foster and J. Potts (2004) who proposed analysis of evolutionary changes that led to the changes in economy and others aspect of life through the three stage level changes - macro, meso and micro (that is also perfectly fit the sustainable development idea think globally act locally). The macro-model of economic evolution based on the similar concept to Schumpeter's conception of the Walrasian 'circular-flow', but explicitly in terms of generic rules. Building on the 'bimodality' between the rule and its actualizations in carriers, there are two distinct levels of macro coordination, namely at the levels of rules per se, and at the level of the rule-populations. The framework for the evolution of the economic (table 1).

Table 1. - Analytic framework for evolution economic

Unit

\section{Trajectory}

\begin{tabular}{l|l|l}
\hline Micro & Agent / agency, rules for operations & (1) Creativity / access \\
& Rule carrier, complex system of rules & (2) Learning / imitation \\
\hline Meso & Generic unit & (3) Normalization \\
& Rule and its carrier population & $(1)$ Origination \\
\hline Macro & (2) Adoption \\
& Whole economy & $(3)$ Retention \\
\hline Complex self-organized system of & $\begin{array}{l}(1) \text { De-coordination } \\
\text { meso units }\end{array}$ & (2) Re-coordination \\
\hline
\end{tabular}

Source: (Dopfer, Potts, 2007: 6)

The analytic framework gives us an idea that all changes in the local level will reach the macrolevel, but formation of new order could not be built only on cumulative effect of local changes. It could be formed by multiplier effect of changes on all levels. Underline, that economic development and evolution could not be separated from social and environmental factors (its fundamentally confirmed by economic theories from traditional economy with the factors of production which includes capital, labour, natural resources and entrep- reneurship to latest one, like behavioral school that assumes that person and his/her behavior are the bases for economic growth). In this context the evolution of economic inextricably is connected with the society and environment, and so, with the concept of sustainable development.

In this paper we focused on the macro-level and represented underneath the short description of economic background of every key step on the progress of sustainable development (table 2).

\section{Table 2. - Historic economic framework for sustainable development}

\begin{tabular}{|c|c|c|}
\hline Dates & SD milestones & Economic milestones \\
\hline 1972 & $\begin{array}{l}\text { UN Conference } \\
\text { on the Human } \\
\text { Environment, } \\
\text { Stockholm }\end{array}$ & $\begin{array}{l}\text { 1971-1972 witnessed a sluggish performance of the world economy in terms of both } \\
\text { production and trade. } \\
\text { The rate of growth of aggregate production of goods and services remained at about } \\
4 \text { per cent in } 1971 \text {, not much more than that of the previous year. } \\
\text { Although this rate fell short of the First United Nations Development Decade's annual } \\
\text { average of } 5.3 \text { per cent, a worldwide recession, at times considered a possibility, was } \\
\text { averted. } \\
\text { Moreover in 1970s countries met great inflation }\end{array}$ \\
\hline 1987 & $\begin{array}{l}\text { Brundtland } \\
\text { Report }\end{array}$ & $\begin{array}{l}\text { The world economy appeared to be set in a slow growth path, which was likely to } \\
\text { delay the great adjustments required at the national and international levels. } \\
\text { The modest expansion that characterized the world economy during most of the first } \\
\text { half of the } 1980 \text { s persisted in } 1986 \text {. Inflation had decelerated considerably and industrial } \\
\text { countries were entering their fifth year of expansion, though at a slow pace. } \\
\text { The Need to be mentioned - Black Monday on October } 19^{\text {th }}, 1987-\text { a sudden, severe, } \\
\text { and largely unexpected stock market crash that struck the global financial market system. }\end{array}$ \\
\hline 1992 & $\begin{array}{l}\text { UN Conference } \\
\text { on Environment } \\
\text { and } \\
\text { Development, } \\
\text { Rio de Janeiro }\end{array}$ & $\begin{array}{l}\text { The early 1990s recession described the period of economic downturn affecting much } \\
\text { of the Western world in the early 1990s, believed to be caused by restrictive monetary } \\
\text { policy enacted by central banks primarily in response to inflation concerns, the loss of } \\
\text { consumer and business confidence as a result of the } 1990 \text { oil price shock, the end of the } \\
\text { Cold War and the subsequent decrease in defense spending, the savings and loan crisis } \\
\text { and a slump in office construction resulting from overbuilding during the } 1980 \text { s. }\end{array}$ \\
\hline 1997 & $\begin{array}{l}\text { Rio+5 } \\
\text { Conference, } \\
\text { New York }\end{array}$ & $\begin{array}{l}\text { The year } 1997 \text { was relatively successful for the world economy (world GDP was the } \\
\text { highest figure in the last decade). } \\
\text { The development was regionally uneven - the fastest developing area, regardless of } \\
\text { the end-of-the-year crisis, was still Asia, whereas the former CIS countries focused on } \\
\text { stopping the economic downfall. } \\
\text { The world's major industrial countries continued to display a modest economic growth } \\
\text { - among the G7 countries the USA, Canada and Great Britain were strong leaders. }\end{array}$ \\
\hline
\end{tabular}


Dates SD milestones

2002 UN World Summit on Sustainable Development, Johannesburg

2012 Conference on Sustainable Development "Rio+20"

\section{Economic milestones}

The early 2000 s recession was a decline in economic activity which mainly occurred in developed countries.

The recession in industrialized countries was not as significant as either of the two previous worldwide recessions. Some economists in the United States objected to characterize it as a recession since there were no two consecutive quarters of negative growth

After a marked slowdown in 2011, global economic growth would likely remain tepid in 2012, with most regions expanding at a pace below potential. In the face of subdued growth, the jobs crisis continued with global unemployment still above its pre-crisis level and unemployment in the euro area rising rapidly.

National and international concerted policies should be enacted on multiple fronts in order to break out of the vicious cycle of deleveraging, rising unemployment, fiscal austerity and financial sector fragility in developed economies.

The global economy expanded during 2014 at a moderate and uneven pace. Legacies from the global financial crisis continued to weigh on growth, while the new challenges had emerged, including geopolitical conflicts such as in Ukraine and the Ebola epidemic.

Unemployment figures remained historically high in some regions, but appeared to have stopped rising. While global inflation remained subdued, the spectrum ranges from deflation risks in the euro area to high inflation in some developing countries.

Foreign direct investment inflows remained the most stable and relevant source of financing for developing countries whereas portfolio capital flows were highly sensitive to changes in risk appetite.

Source: build by authors on the base Regional Economic Updates. World Bank Online recourse https://www.worldbank.org/; World Economic Outlook Online recourse https://www.imf.org/; World Economy Survey. Online recourse www.un.org

The sustainable development milestones through the prism of economic development shows that cyclical economic development and its accelerating character leads to the acceleration of sustainable development measures. As soon as economic evolution accompanied with technological development (ages of economic evolution), increasing the level of consumption (and life, in general) and reconfiguration of political power - the SD framework should evolve along with these processes. Moreover, each economic collapse (or problem) starts a new stage of international conversations about an access to the resources and environmental consequences of economic activities that at the end leads to new documents concerning SD. These new SD agreements become a new era in the socio-economic regulations.

Systematization and analysis of economic development through the prism of sustainable development give us a clue for understanding instigators in the sustainable development evolution (fig. 3 ):

- The necessity of overcoming economic resections and crises in the most efficient and effective way. That means that we also need the new ideas, new imperatives for development and basis for overcoming social inequity which is deepening during every economic trouble and slows down the reforming because of low governmental support

- The increasing world inequality which exacerbates the global imbalance and at the end slow down the world economic development.

Emphasize, that there are not the only reasons for sustainable development evolution, in the framework of the paper we definitely concentrated on one particular aspect - the economic evolution and its influence on the process.

\section{Discussion and Conclusions}

Evolutionary changes in the economy created the background and incentives to the sustainable development concept progress. The main idea of sustainable development, which could be shortly described like balancing between the scarcity of resources and infinity of ideas (desires) for an uncertain long period of time - consistent with the basic principles of the economy. That gives us possibility to predict when the next step in sustainable development will be done in accordance with the world economic dynamic.

Nevertheless, the meeting itself and signing the next stack of agreement do not guaranteed the qualitative changes in the sustainable development progress. These changes become possible when we have come through all stages of evolutionary development - de-coordination, re-coordination, new order (table 1). In the framework of our topic that means that the first phase corresponds to the emergence of the changes on the micro and meso levels/ this is a creation of a point of disturbance, which could be a potential source of growth or change. This will happen only if problems could not be effectively solved at meso level and the number or scale of the problems has been constantly increasing. The second phase corresponds to the process of re-coordination of macrolevel (macro order) as a result of continuing dissatisfaction of local unites and the impossibility of meso level to solve them. The new innovative approaches and practices have become a part of the order. The structure of stabilizing and adapting to responses has been presented. This phase corresponds to what Joseph Schumpeter inferred by 'creative destruction' or Stan Metcalfe calls this 'restless capitalism' referring to a turbulent but continuously selforganizing and reforming the complex structure of knowledge. The third phase has created the new order, different from the older one by its approaches, methods, tools for solving problems which rose from the microlevel and also added through globalization processes and openness. Sustainable development is evolved.

The next step of our research will be systematization of evolving of sustainable development in different countries through the view of three mentioned stages for creating recommendations how governments and international communities can influence on these processes. 


\section{REFERENCES}

Akhmedova, M. G. (2019). On Society Sustainable Development. Revista Inclusiones, 6, 278-287.

Brewer, A. (2008). Adam Smith's stages of history (Discussion Paper No. 08/601). Bristol: University of Bristol.

Cisneros-Saguilána, Pedro \& Gallardo-López, Felipe \& LópezOrtí zb, Octavio \& Rosado, Ruiz \& Herrera-Haroc, José G. \& Hernández-Castro, Elí as (2015). Current Epistemological Perceptions of Sustainability and Its Application in the Study and Practice of Cattle Production: A Review. Agroecology and Sustainable Food Systems. 39 (8): 885-906. DOI: https:// doi.org/10.1080/21683565.2015.1050148

Dopfer, Kurt \& Potts, Jason (2007). The General Theory of Economic Evolution. London, Routledge. DOI: https://doi.org/ 10.4324/9780203507407.

Foster, J. and Potts, J. (2004). Micro-Meso-Macro. Journal of Evolutionary Economics, 14 (3): 264-279.

Hardin, G. (1968). The Tragedy of the Commons. Science. 162 (3859): 1243-1248. Retrieved from http://science.sciencemag.org/content/162/3859/1243.

Hobbes, T. (2010). Leviathan, or the matter, forme, and power of a commonwealth, ecclesiastical and civill. New Haven, CT: Yale University Press.

Kates, R. W., Parris, T. M., Leiserowitz, A. A. (2005). What is sustainable development? Goals, indicators, values, and practice. Environ. Sci. Policy Sustain. Dev. 47: 8-21.

Landes, D. (1998). The Wealth and Poverty of Nations: Why Some are so Rich and Others so Poor. London: Abacus.

Levit, Georgy S. (2000). The Biosphere and the Noosphere Theories of V. I. Vernadsky and P. Teilhard de Chardin: A Methodological Essay. Retrieved from https://web.archive.org/web/20050517081543/http://www2.uni-jena.de/biologie/ ehh/personal/glevit/Teilhard.pdf.

Meadows, Donella H., Meadows, Dennis L., Randers, Jørgen, Behrens III, William W. (1972). The Limits to Growth. A Report for the Club of Rome's Project on the Predicament of Mankind. New York: Universe Books.

Mebratu, D. (1998). Sustainability and sustainable development: Historical and conceptual review. Environ. Impact Assess. Rev. 18: 493-520. Retrieved from https://linkinghub.elsevier.com/retrieve/pii/S0195925598000195.

Mensah, J., \& Ricart Casadevall, S. (2019). Sustainable development: Meaning, history, principles, pillars, and implications for human action: Literature review. Cogent Social Sciences, 5(1), 1653531. DOI: https://doi.org/10.1080/23311886.2019.1653531.

Mokyr, J. (2002). The Gifts of Athena: Historical Origins of the Knowledge Economy. Princeton, NJ: Princeton University Press.

Nell, E. (1998). The General Theory of Transformational Growth. Cambridge: Cambridge University Press.

Our Common Future (1987). Report of the World Commission on Environment and Development. Retrieved from http://www.undocuments.net/our-common-future.pdf.

Rosling, Hans (2012). How Did the World Population Change? Gap Minder. Retrieved from https://www.gapminder.org/ answers/how-did-the-world-population-change/.

Silverberg, G. and Verspagen, B. (2005). Evolutionary Theorizing on Economic Growth. In: The Evolutionary Foundations of Economics. Cambridge: Cambridge University Press.

Sowell, Thomas (1967). The 'evolutionary' economics of Thorstein Veblen, Oxford Economic Papers, 19 (2): 177-198. DOI: https:/ /doi.org/10.1093/oxfordjournals.oep.a041044.

Svizzero, S., \& Tisdell, C. A. (2016). Economic evolution, diversity of societies and stages of economic development: A critique of theories applied to hunters and gatherers and their successors. Cogent Economics \& Finance, 4(1), 1161322. DOI: https://doi.org/10.1080/23322039.2016.1161322.
White, L. A. (1959). The evolution of culture: The development of civilization to the fall of Rome. New York, NY: McGraw-Hill Book.

Witt, U. (2016). Rethinking Economic Evolution: Essays on Economic Change and Its Theory. Edward Elgar Publishing. DOI: https://doi.org/10.1007/s10818-018-9269-z.

Zhao, J., Liang, X., Zhang, X. (1999). System analysis on the definition of sustainable development. Acta Ecol. Sin. 19, 393398.

Zharova, L. (2017). Contemporary Managerial Theories Transformation in Framework of Sustainable Development. MIND Journal, 4. Retrieved from https://mindjournal.wseh.pl/sites/ default/files/article/03-18/contemporary_managerial_theoriestransformation_in_framework_of_sustainable_development.pdf.

Zoheir, Tafer, Abbar, Mohamed (2017). Corporate Social Responsibility: The Misty Concept. International Journal of Academic Research in Economics and Management Sciences, 6 (1): 275-285. DOI: https://doi.org/10.6007/IJAREMS/v6-i1/ 2712 .

\section{LIST OF REFERENCE LINKS}

Akhmedova M. G. On Society Sustainable Development. Revista Inclusiones. 2019. 6: 278-287.

Brewer A. Adam Smith's stages of history (Discussion Paper No. 08/601). Bristol: University of Bristol, 2008.

Cisneros-Saguilána P., Gallardo-López F. etc. Current Epistemological Perceptions of Sustainability and Its Application in the Study and Practice of Cattle Production: A Review. Agroecology and Sustainable Food Systems. 2015. 39 (8): 885906. DOI: https://doi.org/10.1080/21683565.2015.1050148.

Dopfer K., Potts J. The General Theory of Economic Evolution. London: Routledge, 2007. DOI: https://doi.org/10.4324/ 9780203507407.

Foster J., Potts J. Micro-Meso-Macro. Journal of Evolutionary Economics. 2004. 14 (3): 264-279.

Hardin G. The Tragedy of the Commons. Science. 1968. 162 (3859): 1243-1248. URL: http://science.sciencemag.org/content/162/ $3859 / 1243$.

Hobbes T. Leviathan, or the matter, forme, and power of a commonwealth, ecclesiastical and civill. New Haven, CT: Yale University Press, 2010.

Kates R. W., Parris T. M., Leiserowitz A. A. What is sustainable development? Goals, indicators, values, and practice. Environ. Sci. Policy Sustain. Dev. 2005. 47: 8-21.

Landes D. The Wealth and Poverty of Nations: Why Some are so Rich and Others so Poor. London: Abacus, 1998.

Levit G. S. The Biosphere and the Noosphere Theories of V. I. Vernadsky and P. Teilhard de Chardin: A Methodological Essay. 2000. URL: https://web.archive.org/web/20050517081543/ http://www2.uni-jena.de/biologie/ehh/personal/glevit/ Teilhard.pdf.

Meadows D. H., Meadows D. L., Randers J., Behrens III W. W. The Limits to Growth. A Report for the Club of Rome's Project on the Predicament of Mankind. New York: Universe Books, 1972.

Mebratu D. Sustainability and sustainable development: Historical and conceptual review. Environ. Impact Assess. Rev. 1998. 18: 493-520. URL: https://linkinghub.elsevier.com/retrieve/pii/ S0195925598000195.

Mensah J., Ricart Casadevall S. Sustainable development: Meaning, history, principles, pillars, and implications for human action: Literature review. Cogent Social Sciences. 2019. 5(1), 1653531. DOI: https://doi.org/10.1080/23311886.2019.1653531.

Mokyr J. The Gifts of Athena: Historical Origins of the Knowledge Economy. Princeton, NJ: Princeton University Press, 2002.

Nell E. The General Theory of Transformational Growth. Cambridge: Cambridge University Press, 1998. 
Our Common Future. Report of the World Commission on Environment and Development. 1987. URL: http://www.un-documents.net/our-common-future.pdf.

Rosling H. How Did the World Population Change? Gap Minder. 2012. URL: https://www.gapminder.org/answers/how-didthe-world-population-change/.

Silverberg G., Verspagen B. Evolutionary Theorizing on Economic Growth. In: The Evolutionary Foundations of Economics. Cambridge: Cambridge University Press, 2005.

Sowell Th. The 'evolutionary' economics of Thorstein Veblen. Oxford Economic Papers. 1967. 19 (2): 177-198. DOI: https:/ /doi.org/10.1093/oxfordjournals.oep.a041044.

Svizzero S., Tisdell C. A. Economic evolution, diversity of societies and stages of economic development: A critique of theories applied to hunters and gatherers and their successors. Cogent Economics \& Finance. 2016. 4(1), 1161322. DOI: https:// doi.org/10.1080/23322039.2016.1161322.
White L. A. The evolution of culture: The development of civilization to the fall of Rome. New York, NY: McGraw-Hill Book, 1959.

Witt U. Rethinking Economic Evolution: Essays on Economic Change and Its Theory. Edward Elgar Publishing, 2016. DOI: https:// doi.org/10.1007/s10818-018-9269-z.

Zhao J., Liang X., Zhang X. System analysis on the definition of sustainable development. Acta Ecol. Sin. 1999. 19: 393-398.

Zharova L. Contemporary Managerial Theories Transformation in Framework of Sustainable Development. MIND Journal. 2017. 4. URL: https://mindjournal.wseh.pl/sites/default/files/article/ 03-18/contemporary_managerial_theories_transformation_inframework_of_sustainable_development.pdf.

Zoheir T., Abbar M. Corporate Social Responsibility: The Misty Concept. International Journal of Academic Research in Economics and Management Sciences. 2017. 6 (1): 275285. DOI: https://doi.org/10.6007/IJAREMS/v6-i1/2712.

Любов Жарова,

Економіко-гуманітарний університет (м. Бельсько-Бяла, Польща)

e-mail: zharova.l@gmail.com, ORCID 0000-0002-3568-775X

Анна Чечель,

Донеиький державний університет управління (м. Маріуполь, Україна)

e-mail: annachechel.ac@gmail.com,ORCID 0000-0003-4307-5574

\section{ВЗАЕМОЗВ'ЯЗОК СТАЛОГО РОЗВИТКУ ТА ЕВОЛЮЦІЙНОЇЕКОНОМІКИ КРІЗЬ ПРИЗМУ ІСТОРИЧНИХ ПЕРЕТВОРЕНЬ}

Головною гіпотезою пропонованого дослідження є ідея, що сталий розвиток ґрунтується на постійній за змістом ідеї, але задекларовані пріоритети, методи та інструменти постійно розвиваються, і ці еволюційні процеси відбуваються одночасно з економічним розвитком. Комплексний аналіз етапів еволюції та прогнозування економічного розвитку дасть уявлення про майбутні пріоритети сталого розвитку. Еволюційні зміни в економіці створюють передумови та стимули до поступу концепції стійкого розвитку. Основна ідея сталого розвитку, яку можна коротко охарактеризувати як балансування між дефіцитом ресурсів та нескінченністю ідей (бажань) протягом невизначено тривалого періоду часу, відповідає основним принципам економіки, що дає нам можливість передбачити, коли буде зроблено наступний крок у сталому розвитку відповідно до світової економічної динаміки. Систематизація та аналіз економічного розвитку крізь призму сталого розвитку дають нам уявлення про точки збурення еволюції сталого розвитку, що актуалізують необхідність подолання економічних рецесії та криз найбільш ефективним та інновативним способом. Це означає, що потрібні нові ідеї, нові імперативи розвитку та основи для подолання соціальної нерівності, яка поглиблюється під час економічної турбулентності та уповільнює реформування через низьку підтримку держави. Серед інших стимулів поступу виділено: зростаючу світову нерівність, яка посилює глобальний дисбаланс і, врешті-решт, сповільнює світовий економічний розвиток. У статті доведено, що поступ стає можливим за умов проходження всіх етапів еволюційного розвитку -де-координації, повторної координації, нового порядку. Перша фаза - це створення точки збурення, яка може бути потенційним джерелом зростання або змін. Друга фаза - процес перекоординації на макрорівні (макропорядок) внаслідок постійного невдоволення локальних об'єднань та неможливості задовольнити їх на всіх рівнях. Третя фаза - створення нового порядку, що відрізняється від старого за своїми підходами, методами та інструментами для вирішення проблем, які виникли на мікрорівні, а також додалися через глобалізаційні процеси та відкритість. Саме так відбувається еволюція сталого розвитку, а процеси ці можуть відстежуватися і передбачатися через еволюційну економіку.

Ключові слова: еволюційна економіка; економічна історія; сталий розвиток; економіка; розвиток; економічна теорія; глобалізація.

(C) Liubov Zharova, Anna Chechel

Надійшла до редакції: 26.03.2020

Прийнята до друку: 10.04.2020 